\title{
Logical Cornestones of Judaic Argumentation Theory
}

\author{
Andrew Schumann
}

Published online: 26 September 2012

(C) The Author(s) 2012. This article is published with open access at Springerlink.com

\begin{abstract}
In this paper, the four Judaic inference rules: qal wa-homer, gezerah śawah, heqeš, binyan 'av are considered from the logical point of view and the pragmatic limits of applying these rules are symbolic-logically explicated. According to the Talmudic sages, on the one hand, after applying some inference rules we cannot apply other inference rules. These rules are weak. On the other hand, there are rules after which we can apply any other. These rules are strong. This means that Judaic inference rules have different pragmatic meanings and this fact differs Judaic logic from other ones. The Judaic argumentation theory built up on Judaic logic also contains pragmatic limits for proofs as competitive communication when different Rabbis claim different opinions in respect to the same subject. In order to define these limits we build up a special kind of syllogistics, the so-called Judaic pragmatic-syllogistics, where it is defined whose opinion should be choosen in a dispute.
\end{abstract}

Keywords qal wa-ḥomer . Gezerah šawah . Heqeš . Binyan 'av . Judaic inference rules · Judaic pragmatic-syllogistics

In Judaism very difficult schemata of logical reasoning adequate for massiveparallelism and concurrency of Jewish religious thought have been developed (Schwarz 1901, 1897; Jacobs 1984; Abraham et al. 2010). Recall that the oldest Hebrew commentary tradition (i.e. Tannaitic tradition) recognises mainly three collections of logical inference rules:

\footnotetext{
A. Schumann ( ()

Wyższa Szkoła Informatyki i Zarządzania, ul. Sucharskiego 2, 35-225 Rzeszów, Poland e-mail: Andrew.Schumann@gmail.com
} 
- the seven rules of Hillel;

- the thirteen rules of Rabbi Ishmael (they include the six rules of Hillel) for inferring new legislative (halakhic) aspects of the Torah (Hirschfeld 1840);

- the thirty-two rules of Rabbi Eliezer ben Yosi ha-Gelili for inferring new narrative (haggadic) aspects of the Scripture including the Prophets (Nevi'im) and the Writings (Ketuvim) also (however, there is an opinion that some of these rules were not included into the rules of Rabbi Ishmael and are aimed for inferring new halakhic aspects of the Torah too) (Hirschfeld 1847).

An important fact is that Maimonides (1135-1204), one of the most authoritative rabbis of all periods, asserted that Jewish legal arguments belong to the sphere of dialectics, in particular the thirteen hermeneutic principles of Rabbi Ishmael by which the Torah is expounded, might be treated as Aristotelian topoi and never as deductive syllogisms. Only Karaites suggested to use Aristotelian deductive syllogisms as legal arguments, thus they denied the significance of Judaic logical inference rules.

The point is that in Judaism something like Ecumenical Councils of the Christian Church has never appeared and the plurality of opinions has ever supposed in respect to plenty of subjects and in many cases it has been even in advance. It is possible to act legitimately even if we follow contrary viewpoints such as Shammai and Hillel's opposite viewpoints who ever debated:

תני רב יחזקאל עשה כדברי בית שמאי עשה כדברי בית הלל עשה

Rav Yehezkel learnt: If one acts in accordance with the opinion of party of Shammai he has acted [legitimately]; if he acts in accordance with the opinion of party of Hillel he has acted [legitimately] (Berakhot 11a).

Another example, it is allowed to obey the law either according to Rabbi or according to other sages even in cases both opinions are contrary:

אמר רבה בר חנא אמר ר' חייא עשה כדברי רבי עשה כדברי חכמים עשה

Rabbah bar Hannah said in the name of R. Hiyya, "If one acted according to Rabbi he has acted [legitimately]; [If one acted] according to the sages he has acted [legitimately]" (Baba Bathra 124a-b).

Within the plurality of opinions we cannot use deductive syllogisms as legal arguments, because syllogistics is developed by means of a holistic standpoint that stands in contradiction to Judaic presuppositions of plurality and to dialectics as a whole. The Christian culture inherits the Roman approach to making decision in disputes in respect to legal subjects, when a final decision should be sole:

The answers of jurists are the decisions and opinions of persons authorized to lay down the law. If they are unanimous their decision has the force of law; if they disagree, the judge may follow whichever opinion he chosses, as is ruled by a rescript of the late emperor Hadrian (Gaius, Institutes, 1.7).

Adopting the Roman totalitarian viewpoint allowed the Church Fathers to implement the Roman legal approach in organizing the Ecumenical Councils for making ultimate decisions in religious subjects. On contrary, Judaic reasoning has 
been presented as a massive-parallel and concurrent proof system that is traditionally called dialectics (Roth 1986; Schumann 2010, 2011a, b, 2012).

Thus, Judaism presupposes a plurality of opinions within appropriate pragmatic limits. If we reconstruct the Judaic argumentation theory, i.e. pragmatic limits in using logical tools, we will find out that all proofs of Judaic sages may be classified at least into the following three groups from the pragmatic standpoint:

- Proofs as trees. Some premises in reasoning are compatible, i.e. they can be combined in the same deductions. Therefore it has no sense to distinguish, whom (which authority) the premises belong to.

- Proofs as parallel processes. Some premises are incompatible, they never occur in the same deductions, but they are concurrent, i.e. used in parallel, disjoint deductive exchanging of input data. For example, the sages maintained that in some cases the inference rule heqes cannot be involved in the same deduction more than two times: "that which is learnt through a heqes does not in turn teach through a heqes" (Zevachim 49b). In other words, the inference rule heqeš may be used only concurrently.

- Proofs as competitive communication. Some inference rules of Judaic logic are competitive, i.e. they have a communication among themselves, though they are incompatible and give different results. In this case we should distinguish, whom (which authority) the premises belong to.

As we see, only the first group of Judaic inference rules could find a standard formalisation within the framework of conventional logic. The two others can be formalized only within a version of behavioral logic containing proof techniques for massive-parallel and concurrent deductions. Evidently, this logic should deal with non-well-founded abstract objects. Let us remember that non-well-founded entities have structure where the set-theoretic axiom of foundation is not valid (Aczel 1988; Schumann 2008). For instance, infinite trees or threes with cycles are non-wellfounded. Behaviors may be formalized as non-well-founded trees. Thus, it is possible to aim obtaining a behavioral (non-well-founded) logic, formalizing the Judaic reasoning. For verifying this formalisation of Judaic proof system it is possible to build up a new version of process calculus and process semantics.

In conventional logic (in particular in Aristotelian syllogistics) we have a finite set of axioms and inference rules by using which we obtain all true propositions. In behavioral (non-well-founded) logic the set of premises (axioms) may be infinite, some derivations may be parallel, some others competitive, and some others cyclic, etc.

The development of behavioral logic is very promising today. There are lots of its versions suited to discourse and reasoning about sequential behavior: Hoare logic, algorithmic logic, process logic, and dynamic logic. However, extending these logics to concurrent behavior has proved problematic. These logics are unapplied also to analyzing massive-parallel process. Therefore formalizing a Judaic version of behavioral logic could find a lot of practical applications in modern computer sciences. 
Nevertheless, we will not build up the whole Judaic behavioral logic in this paper; we limit ourselves just to considering logical cornerstones of Judaic argumentation theory.

First of all, recall that a proof (or derivation) of a well-formed formula $S$ from a set of premises $U$ is a finite tree such that:

- $S$ is the root of the tree and it is called the end-formula.

- The leaves of the tree are all axioms or members of $U$.

- Each child node of the tree is obtained from its parent nodes by an inference rule, i.e. if $S$ is a child node of $S_{1}, \ldots, S_{n}$, then $\frac{S_{1}, \ldots, S_{n}}{S}$ is an instance of a rule.

In the Judaic argumentation theory, the set of all propositions (all cases of laws or prohibitions) of the Torah is regarded as set $U$ of premises. Thereby in drawing derivation trees, the following inference rules are most demanded:

1. Qal wa-homer [קל וחומר] ('parallel concurrent deductions'), this rule partly corresponds to the scholastic proof a fortiori ('a minori ad majus' or 'a majori ad minus'), according to the latter what applies in less important cases will apply in more important ones too, i.e. this rule allows to entail from the simple to the complex or vice versa (Abraham et al 2009; Schumann 2011). However, there are important distinctions from the scholastic proof a fortiori. The process of deduction in the qal wa-homer is proceeded under the assumption that the inferred statement conclusion may contain nothing more than is found in the premise. This limitation is called the dayo principle. A syllogism implicitly drawn from a minor case upon a more important one: "If $X$ is true of $Y$ and $Z$ is of greater weight than $Y$, then how much more $X$ must be true of $Z$ (but not more than of $Z$ )." Example: using the following passage as premise "If thou meet thy enemy's ox or his ass going astray, thou shalt surely bring it back to him again" (Ex. 23:4), we can conclude that if that be one's conduct toward an enemy, how much more should one be considerate toward a friend. In qal wa-homer two or more parallel deductions concur under the following conditions: (1) they have joint premises (2) one deduction of the set of concurrent deductions is much more certain. As a result, a certainty of that deduction is expanded to cases of other concurrent deductions. Notice that qal wa-homer does not hold in Judaic criminal procedure, i.e. by using this rule nobody can be sentenced to an execution.

We could differ the Biblical case of qal wa-homer described above from the more sophisticated way of its application in the Talmud. The point is that quite often a qal wa-homer is used in the Talmud as the basic inference rule of metareasoning, i.e. as reasoning about reasoning, in particular it is applied in relation to differet complexes of derivations (as we see a bit later, namely in propositions Q1-Q6).

2. Gezerah šawah [גזירה שווה] ('analogy'), this rule can be described as proof by analogy, which infers from the similarity of two cases that the legal decision given for the one holds for the other also. This rule may be valid if we observe the use of a similar phrase, word, or root of word in Hebrew in different contexts. In Talmudic tradition it is claimed that every gezerah šawah must have been handed down from Sinai. No one may draw a conclusion from analogy upon his own authority.

3. Heqeš [היקש], this Hebrew word means a comparison based on the close connection of two subjects in one and the same passage of the Torah. According to 
heqes, if two particulars are connected in the law by a common general, the same provisions in regard to one of them are under certain circumstances applicable also to the other. For instance, women are free from the performance of all periodical rites and religious duties kept by male Israelites. However, we deduce by heqeš that it is incumbent on women to obey prohibitory commandments, because there is a passage in the Torah:

Speak unto the children of Israel, when a man or woman shall commit any sin that men commit, to do a trespass against the Lord, and that person be guilty (Num. 5:6),

where women and men belong to one general in regard to a trespass against the law. Another example of heqes appears to prove that a wife is taken in matrimony by means of a written contract of marriage. There is a statement:

And when she is departed out of his house, she may go and be another man's wife (Deut. 24:2)

according to that the divorse is made by means of a bill of divorcement. In one verse it is talked about departing out of the house and becoming another man's wife. Hence, this becoming a wife is effected by means of a written document also.

4. Binyan 'av [בנין אב] ('genus'), it unites the third and the fourth rules of Hillel. The example of a genus: "He shall even pour out the blood thereof, and cover it with dust" (Lev. 17:13). This means that all aspects of two actions should be considered in common, e.g. just as the pouring out of the blood is performed with the hand, so must the covering be done with the hand, not with the foot.

Let us denote qal wa-homer, gezerah šawah, heqeš, binyan 'av by q, g, h, b respectivelly.

Definition 1 The derivation, $\operatorname{Der}^{\mathrm{I}}(A, B)$, in Judaic reasoning is a two-placed predicate such that $A$ is a child node and $B$ is a parent node of an appropriate inference rule I (where I is one of the rules from the set $\{\mathrm{q}, \mathrm{g}, \mathrm{h}, \mathrm{b}\}$ ), whereas either $B$ belongs to $U$ or $B$ is a child node of another inference rule $\mathrm{I}_{0}$ (from the same set $\{\mathrm{q}, \mathrm{g}, \mathrm{h}, \mathrm{b}\})$. In the second case we can write $\operatorname{Der}^{\mathrm{I}}\left(A, \operatorname{Der}^{I_{0}}(B, C)\right)$, where $C$ either belongs to $U$ or is a child node of another inference rule $\mathrm{I}_{1}$ (from $\{\mathrm{q}, \mathrm{g}, \mathrm{h}, \mathrm{b}\}$ ) and then $\operatorname{Der}^{\mathrm{I}}\left(A, \operatorname{Der}^{I_{0}}\left(B, \operatorname{Der}^{I_{1}}(C, D)\right)\right.$, and so on. The predicate $\operatorname{Der}^{\mathrm{I}}(A, B)$ is read as follows: "the standpoint $A$ is provable by the argument $B$ through $\mathrm{I}$;" in the Talmudic phraseology: " $B$ teaches $A$ through I" or " $A$ is learnt from $B$ through I."

By this definition, the Judaic derivation supposed in proof argumentation is a reflexive and transitive relation. Indeed, the standpoint $A$ is provable by the argument $A$ and if the standpoint $A$ is provable by the argument $B$ and $B$ is provable by the $\operatorname{argument} C$, then $A$ is provable by the argument $C$. Formally, the binary relation $\operatorname{Der}_{0}^{\mathrm{I}}$ of derivation is defined as the least relation satisfying: whenever there is a proof tree containing $P$ in the conclusion and $Q$ among the premises, then $\operatorname{Der}_{0}^{\mathrm{I}}(P, Q)$ holds. Further, define $\operatorname{Der}^{\mathrm{I}}$ to be the reflexive and transitive closure of $\operatorname{Der}_{0}^{\mathrm{I}}$.

Definition 1 allows us to commit all derivations trees to writing. There is no end of possible combinations taking into account the sets of premises (any cases of laws 
or prohibitions) and inference rules and, as a result, there is a plenty of derivation predicates. However, not all combinations are acceptable from the standpoint of Judaic pragmatic limits.

The inference rules q, g, h, b are topoi in the Aristotelian meaning given by him in the Topics. These hermeneutic rules are not deductive, although they may have and have a rigorous logical feature and bear a strict logical derivation sense. Their non-deductiveness consists just in that they belong to human pragmatics, namely they are parts of Judaic speech acts and concern Judaic behaviors. They are not an abstract game in abstract signs as we have in a deductive logic.

Hermeneutic rules of any religious system are topoi in fact. Their goal is to constitute a kind of opinions, the so-called divine standpoint written down in revelation, and a kind of behaviors, the so-called perfect behaviour satisfying divine commandements. On the contrary, the Topics of Aristotle proposes different ways of invention and discovery of arguments in which the propositions rest upon any commonly-held opinions, not only upon divine standpoints. Hence, the Aristotelian dialectics is pluralistic and open for different opposite opinions.

All the possible cases of laws or prohibitions that can be associated with the Holy Scripture form an infinite set of propositions. This set may be appreciably reduced by inference rules of appropriate hermeneutics: Judaic, Karaitic, Catholic, etc. Different canons of rules give different results, but not any possible. Nevertheless, this reduced set is enormous enough still. The number of possible premises is too large; therefore we can ever have opposite opinions. It is not the question of Aristotelian dialectics, but this is a real problem of religious hermeneutics, because the latter should deduce and explain divine standpoints and tell how we must behave, i.e. it should support an unambiguous opinion. There are different ways that allow us to solve this problem.

The Christian way is that all the fundamental religious standpoints have been accepted in Ecumenical Councils by voting. Their members should have voted unanimously and the minority, i.e. all who were discordant have been anathematized as heretics. There is no place for doctrinal discussions. Only one opinion exists forever. Nomocanons (Greek: Nонокаv'́v) were collections of ecclesiastical law in Christian Churches and these collections were based on canon law accepted in ecumenical councils by voting. Since then in the Catholic Church another mean to introduce canon law has appeared as well, in particular decretals (epistolae decretales), the letters of the Pope that formulate decisions in ecclesiastical law. This mean does not assume an opposite opinion or pluralism too.

In Judaism something like Ecumenical Councils or Pope decretals has never taken place. The pluralistic nature of Judaic thought has ever postulated. However, in the same measure as in Christianity Judaism needs canon law (halakha) supporting only one opinion. The Christian way is to avoid doctrinal discussions and to anathematize all discordant people. This way of supporting only one opinion in canon law is too simple and not logical. The Judaic way is much more sophisticated. On the one hand, in Judaism doctrinal discussions are ever possible and anathematizing is an extreme case. On the other hand, only one opinion from opposite ones should satisfy canon law (halakha). This contradiction has been solved by metareasoning, i.e. by a logical analysis of pragmatic limits for eventual 
opinions. The metareasoning should avoid some derivation predicates, i.e. reduce the number of deductions. In this paper I will consider first how the subject of Talmudic discussion in relation to halakha affects avoiding some derivations and second how the authority of opinion weighs upon accepting derivations. As we will see these two Judaic means have a rigorous formal-logical meaning. It seems to me that only Judaism has such sophisticated means for deducing univocal canon law.

The Judaic way of unifying opinions may be interesting from the viewpoint of modern argumentation theory as an example of formal metareasoning directed towards establishing univocal standpoints within concrete pragmatic limits.

Our first example of Judaic formal metareasoning concerns restrictions in composing one inference rule with another when reasoning is about sanctified objects or sacred rites (הקדשים], all the thinks connected to the Temple). It is known that within other subjects we have no similar restrictions:

אמר ר' יוחנן בכל התורה כולה למידין למד מלמד חוץ מן הקדשים שאין דנין למד מלמד

R. Yohanan said: everywhere in the Torah we may draw an inference from something which itself has been inferred, outside the realm of the sacred, wherein we may not draw an inference from something which itself has been inferred (Zevachim 49b).

The start point of discussion concerns the most holy sacrifices, consisting of the burnt-offering ('olah), sin-offering (hat 'at), and guilt-offering ('ašam), if they must be slaughtered in the northern part of the Outer Altar and if their blood must be received in a sacred vessel in this northern part. The problem is that the burntoffering is the only sacrifice mentioned in the Torah whose site of slaughter is unambiguously designated as the north (Lev. 1:11). However, this Biblical verse explicitly considers just a flock burnt-offering meaning a sheep or goat, and we do not know if cows are also included. On the other hand, Lev. 1:10 concerning a flock offering begins with the connective 'and' (the Hebrew letter waw) which is superfluous here. In the previous verse the subject was on a cattle burnt-offering. Therefore by heqeš (appealing to this 'and') rabbis deduce that cows are thus included also as burnt-offering slaughtered in the north.

Now that is the question where all sin-offerings and guilt-offerings must be slaughtered. The Torah (Lev. 6:18) prescribes that the sin-offering be slaughtered "in the place where the burnt-offering is slaughtered," i.e. in the northern part. Nevertheless, nothing is said where the sin-offering blood must be collected. But it can be inferred by a qal wa-homer from the burnt-offering as less stringent.

We know from the Torah (Lev. 7:2) as well that the guilt-offering is to be slaughtered at the same site as the burnt-offering, i.e. in the north. However, nothing is said again where the blood collection must be.

Hence, the problem is that in order to deduce that all three most holy sacrifices (burnt-offering, sin-offering, and guilt-offering) must be slaughtered in the north and their blood must be received there as well, we need to appeal to two-step exegeses, i.e. to apply one inference rule just after another. In Zevachim 49b-51a different two-step combinations of rules from the set $\{\mathrm{q}, \mathrm{g}, \mathrm{h}, \mathrm{b}\}$ are regarded if they may be accepted for the subject of the most holy sacrifices. 
According to the Talmud, the following derivation predicates are strongly forbidden when the subject concerns sanctified objects or sacred rites:

$$
\operatorname{Der}^{\mathrm{h}}\left(A, \operatorname{Der}^{\mathrm{h}}(B, C)\right) \text { is rejected }
$$

i.e. that which is learnt through a heqeř does not in turn teach through a heqě̌.

By (1), we cannot learn by a heqes the guilt-offering from the sin-offering which was learned from the burnt-offering by a heqeř, too. The matter is that as support argumentation it would be insufficient in fact.

According to Rabbi Yohanan bar Nappaḥa' [רבי יוחנן בר נפחא]:

$$
\operatorname{Der}^{\mathrm{g}}\left(A, \operatorname{Der}^{\mathrm{h}}(B, C)\right) \text { is rejected }
$$

i.e. that which is learnt by a heqeš does not in turn teach through a gezerah šawah.

Rabbi Yohanan' notices that a spreading outbreak of leprosy covering the whole is considered as the deduction $\operatorname{Der}^{\mathrm{g}}\left(A, \operatorname{Der}^{\mathrm{h}}(B, C)\right)$. However, the phenomenon of spreading outbreak does not fit within the category of sacred rites; therefore this dual derivation cannot be valid.

$$
\operatorname{Der}^{\mathrm{b}}\left(A, \operatorname{Der}^{\mathrm{h}}(B, C)\right) \text { is rejected }
$$

i.e. that which is learnt through a heqeš cannot in turn teach through a binyan 'av.

This deduction cannot be used as well, we cannot infer 'northward' of guiltoffering from a sin-offering or a burnt-offering by a binyan 'av assuming that these three kinds of sacrifices share the common characteristic of being offerings. The point is that they all are sufficiently different in what they are and who must bring them.

$$
\operatorname{Der}^{\mathrm{h}}\left(A, \operatorname{Der}^{\mathrm{g}}(B, C)\right) \text { is rejected }
$$

i.e. that which is learnt by a gezerah šawah does not in turn teach through a heqeř.

Rav Papa' [רב פפא] proposes the derivation predicate $\operatorname{Der}^{\mathrm{h}}\left(A, \operatorname{Der}^{\mathrm{g}}(B, C)\right)$ for the subject of the most holy sacrifices. However, as rabbis claim, he involves instances in which the gezerah šawah was based on peace and thanksgiving offerings, although in the second step he appeals to tithe (ma'aser šeni), a nonsacred item (hullin).

Thus, according to Rav Papa' we have as follows:

$$
\operatorname{Der}^{\mathrm{h}}\left(A, \operatorname{Der}^{\mathrm{g}}(B, C)\right) \text { is allowed }
$$

i.e. that which is learnt by a gezerah sawah can in turn teach through a heqeš.

In the meantime, the universality of qal wa-homer in respect to heqeš is asserted by all sages:

$$
\operatorname{Der}^{\mathrm{q}}\left(A, \operatorname{Der}^{\mathrm{h}}(B, C)\right) \text { is allowed }
$$

i.e. that which is learnt through a heqeš teaches in turn by a qal wa-homer.

$$
\operatorname{Der}^{\mathrm{g}}\left(A, \operatorname{Der}^{\mathrm{g}}(B, C)\right) \text { is allowed }
$$


i.e. that which is learnt through a gezerah šawah teaches in turn by a gezerah šawah.

Because of rejecting some derivation predicates in the Talmud, we can define the following four new predicates:

Definition 2 The predicate "weak learning of $\mathrm{I}_{i}$ for $\mathrm{I}_{j}$ ", where $\mathrm{I}_{i}, \mathrm{I}_{j}$ from the set $\{\mathrm{q}, \mathrm{g}, \mathrm{h}, \mathrm{b}\}$ means that if we apply the inference rule $\mathrm{I}_{j}$, we cannot just after apply the rule $\mathrm{I}_{i}$.

Hence, propositions (1)-(4) are expressed by predicates "weak learning of $h$ for $h$ ", “weak learning of $g$ for $h$ ", "weak learning of $b$ for $h$ ", "weak learning of $h$ for g", respectively.

Definition 3 The predicate "weak teaching of $\mathrm{I}_{i}$ for $\mathrm{I}_{j}$ ", where $\mathrm{I}_{i}, \mathrm{I}_{j}$ belong to the set $\{\mathrm{q}, \mathrm{g}, \mathrm{h}, \mathrm{b}\}$, means that if we apply the inference rule $\mathrm{I}_{i}$, we cannot just after apply the rule $\mathrm{I}_{j}$.

Obviously that if $\mathrm{I}_{i}$ has a weak teaching for $\mathrm{I}_{j}$, then $\mathrm{I}_{j}$ has a weak learning for $\mathrm{I}_{i}$, i. e. "weak learning of $\mathrm{I}_{i}$ for $\mathrm{I}_{j}$ " $\Rightarrow$ "weak teaching of $\mathrm{I}_{j}$ for $\mathrm{I}_{i}$ ". In other words, the predicate "weak learning" is dual to the predicate "weak teaching", i.e. these predicates assume the dual ordering relations on the set of derivations: " $A$ weakly teaches $B$ " is the same as " $B$ is weakly learnt from $A$." The conditions (1)-(4) can be formulated by predicates "weak teaching of $h$ for $h$ ", "weak teaching of $h$ for $g$ ", "weak teaching of $\mathrm{h}$ for $\mathrm{b}$ ", "weak teaching of $\mathrm{g}$ for $\mathrm{h}$ ”, respectively.

Definition 4 The predicate "strong learning of $\mathrm{I}_{i}$ for $\mathrm{I}_{j}$ ", where $\mathrm{I}_{i}, \mathrm{I}_{j}$ from the set $\{\mathrm{q}, \mathrm{g}, \mathrm{h}, \mathrm{b}\}$ means that if we apply the inference rule $\mathrm{I}_{j}$, we can always apply the rule $\mathrm{I}_{i}$.

This kind of predicates can be exemplified by "strong learning of $h$ for g" satisfying condition (5), by "strong learning of q for h" satisfying condition (6), and by "strong learning of $\mathrm{g}$ for g" satisfying condition (7).

Definition 5 The predicate "strong teaching of $\mathrm{I}_{i}$ for $\mathrm{I}_{j}$ ", where $\mathrm{I}_{i}, \mathrm{I}_{j}$ from the set $\{\mathrm{q}, \mathrm{g}, \mathrm{h}, \mathrm{b}\}$ means that if we apply the inference rule $\mathrm{I}_{i}$, we can always apply the rule $\mathrm{I}_{j}$.

For instance, "strong teaching of $\mathrm{g}$ for $\mathrm{h}$ " satisfies (5), "strong teaching of $\mathrm{h}$ for q" satisfies condition (6), and by "strong teaching of $\mathrm{g}$ for g" satisfying condition (7). Let us notice that the predicate "strong teaching" is dual to the predicate "strong learning".

Following the Judaic sages, we may propose now an ordering relation over the set $\{\mathrm{q}, \mathrm{g}, \mathrm{h}, \mathrm{b}\}$. On the basis of propositions (1)-(7), it is possible to order the Judaic inference rules $\mathrm{q}, \mathrm{g}, \mathrm{h}, \mathrm{b}$ by predicates of definitions $2-5$. The tool of ordering is presented by a traditional Judaic way, qal wa-homer. In the Talmudic tractate Zevachim we face the following six reasoning by qal wa-homer, which order the inference rules $\mathrm{q}, \mathrm{g}, \mathrm{h}, \mathrm{b}$.

Q1 If that which is learnt by a heqeř, which cannot teach by a heqers (1), can teach by a qal wa-homer (6) and something is learnt through a gezerah šawah, which can in turn teach by a heqeš, as follows from Rav Papa' (5), then this something can surely teach in turn by a qal wa-homer: 
( ' $\operatorname{Der}^{\mathrm{h}}\left(A, \operatorname{Der}^{\mathrm{h}}(B, Y)\right)$ is rejected' \& ' $\operatorname{Der}^{\mathrm{q}}\left(C, \operatorname{Der}^{\mathrm{h}}(B, Y)\right)$ is allowed' \& ${ }^{\prime} \operatorname{Der}^{\mathrm{h}}\left(A, \operatorname{Der}^{\mathrm{g}}(D, X)\right)$ is allowed' $) \Rightarrow{ }^{\mathrm{C}} \operatorname{Der}^{\mathrm{q}}\left(E, \operatorname{Der}^{\mathrm{g}}(D, X)\right)$ is allowed'.

\begin{tabular}{lllll}
\hline & Weak teaching & Weak learning & Strong teaching & Strong learning \\
\hline heqe ̌̌ & for $\mathrm{h}$ & for $\mathrm{h}$ & for $\mathrm{q}$ & for $\mathrm{g}$ \\
gezerah šawah & - & - & for $\mathrm{h}$ & - \\
qal wa-homer & - & - & - & for $\mathrm{h}$ \\
\multicolumn{2}{l}{ Does qal wa-homer } & have a strong learning for gezerah šawah? & \\
\hline
\end{tabular}

This table shows that, on the one hand, $\mathrm{q}$ has the property to be a strong learning for $\mathrm{h}, \mathrm{g}$ has the property to be a strong teaching for $\mathrm{h}$. On the other hand, $\mathrm{h}$ has the properties to be a strong learning for $\mathrm{g}$ and a strong teaching for $\mathrm{q}$. Taking into account that due to (1) and (6) h is weaker than q, we can infer from minor to major that $\mathrm{q}$ has the property of $\mathrm{h}$ to be a strong learning for $\mathrm{g}$.

Q2 If a heqeš, which cannot in turn teach by a heqeš (1), can teach in turn by a qal wa-homer (6) and a gezerah šawah does teach by a gezerah šawah like itself (7), then this gezerah šawah can surely teach through a qal wa-homer:

( ' $\operatorname{Der}^{\mathrm{h}}\left(A, \operatorname{Der}^{\mathrm{h}}(B, Y)\right)$ is rejected' \& ' $\operatorname{Der}^{\mathrm{q}}\left(C, \operatorname{Der}^{\mathrm{h}}(B, Y)\right)$ is allowed' \& ${ }^{\prime} \operatorname{Der}^{\mathrm{g}}\left(A, \operatorname{Der}^{\mathrm{g}}(D, X)\right)$ is allowed' $) \Rightarrow{ }^{'} \operatorname{Der}^{\mathrm{q}}\left(E, \operatorname{Der}^{\mathrm{g}}(D, X)\right)$ is allowed'.

\begin{tabular}{lllll}
\hline & Weak teaching & Weak learning & Strong teaching & Strong learning \\
\hline heqě̌ & for $\mathrm{h}$ & for $\mathrm{h}$ & for $\mathrm{q}$ & - \\
gezerah šawah & - & - & for $\mathrm{g}$ & for $\mathrm{g}$ \\
qal wa-homer & - & - & - & for $\mathrm{h}$ \\
\multicolumn{2}{l}{ Does gezerah šawah have a strong teaching for qal wa-homer? } & \\
\hline
\end{tabular}

According to this table, on the one hand, $\mathrm{g}$ has the property to be a strong teaching for $\mathrm{g}$. On the other hand, $\mathrm{h}$ has the properties to be a strong teaching for $\mathrm{q}$. Taking into account that due to (1) h is weaker than $g$, we may deduce from minor to major that $\mathrm{g}$ has the property of $\mathrm{h}$ to be a strong teaching for $\mathrm{q}$.

Q3 If a gezerah šawah, which cannot be learnt from a heqě̌, as follows from Rabbi Yohanan bar Nappaha' dictum (2), can nevertheless teach by a heqeš, in accordance with Rav Papa' (5), and a qal wa-homer can be learnt from a heqeš (6), then this qal wa-homer can surely teach by a heqes:

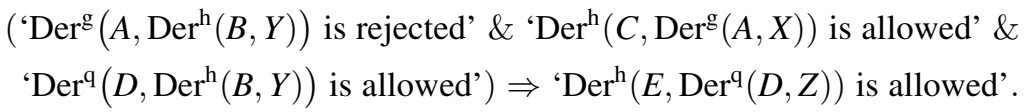




\begin{tabular}{lllll}
\hline & Weak teaching & Weak learning & Strong teaching & Strong learning \\
\hline heqe ̌́ & for $\mathrm{g}$ & - & for $\mathrm{q}$ & for $\mathrm{g}$ \\
gezerah šawah & - & for $\mathrm{h}$ & for $\mathrm{h}$ & - \\
qal wa-homer & - & - & - & for $\mathrm{h}$ \\
Does qal wa-ḥomer & have a strong teaching for heqeš? & & \\
\hline
\end{tabular}

As follows from this table, we assume that $\mathrm{g}$ is weaker than $\mathrm{q}$ ( $\mathrm{g}$ is a weak learning for $\mathrm{h}$, although $\mathrm{q}$ is a strong learning for $\mathrm{h}$ ). Further, $\mathrm{g}$ has the property to be a strong teaching for $\mathrm{h}$. Then taking into account that $\mathrm{g}$ is weaker than $\mathrm{q}$, we can entail from minor to major that $\mathrm{q}$ has the property of $\mathrm{g}$ to be a strong teaching for $\mathrm{h}$.

Q4 If a gezerah šawah, which cannot be learnt from a heqeš, in accordance with Rabbi Yohanan bar Nappaha' dictum (2), can teach by a gezerah šawah and a qal wa-homer can be learnt by a heqeš (6), then this qal wa-homer can teach by a gezerah šawah:

('Der' ${ }^{\mathrm{g}}\left(A, \operatorname{Der}^{\mathrm{h}}(B, Y)\right)$ is rejected' \& ${ }^{\prime} \operatorname{Der}^{\mathrm{g}}\left(C, \operatorname{Der}^{\mathrm{g}}(A, X)\right)$ is allowed' \& ' $\operatorname{Der}^{\mathrm{q}}\left(D, \operatorname{Der}^{\mathrm{h}}(B, Y)\right)$ is allowed' $) \Rightarrow \operatorname{Der}^{\mathrm{g}}\left(E, \operatorname{Der}^{\mathrm{q}}(D, Z)\right)$ is allowed'.

\begin{tabular}{lllll}
\hline & Weak teaching & Weak learning & Strong teaching & Strong learning \\
\hline heqeš & - & for $\mathrm{g}$ & for $\mathrm{q}$ & - \\
gezerah šawah & for $\mathrm{h}$ & - & for $\mathrm{g}$ & for $\mathrm{g}$ \\
qal wa-ḥomer & - & - & - & for $\mathrm{h}$ \\
\multicolumn{2}{l}{ Does qal wa-homer have a strong teaching for gezerah šawah? } & \\
\hline
\end{tabular}

In the table we see that $\mathrm{g}$ is weaker than $\mathrm{q}$ (indeed, $\mathrm{g}$ is a weak teaching for $\mathrm{h}$, but $\mathrm{q}$ is a strong learning for $\mathrm{h}$ ), at the same time $\mathrm{g}$ has the property to be a strong teaching for $\mathrm{g}$. From minor to major we conclude that $\mathrm{q}$ has the same property to be a strong teaching for $\mathrm{g}$.

Q5 If a gezerah šawah, which cannot be learnt by a heqeš, in accordance with Rabbi Yohanan bar Nappaha' dictum (2), can teach by a qal wa-homer and a qal wa-homer can be learnt from a heqeš (6), then this qal wa-homer can teach by a qal wa-homer:

('Der ${ }^{\mathrm{g}}\left(A, \operatorname{Der}^{\mathrm{h}}(B, Y)\right)$ is rejected' \& ${ }^{\prime} \operatorname{Der}^{\mathrm{q}}\left(C, \operatorname{Der}^{\mathrm{g}}(A, X)\right)$ is allowed' \& ' $\operatorname{Der}^{\mathrm{q}}\left(D, \operatorname{Der}^{\mathrm{h}}(B, Y)\right)$ is allowed' $) \Rightarrow{ }^{\prime} \operatorname{Der}^{\mathrm{q}}\left(E, \operatorname{Der}^{\mathrm{q}}(D, Z)\right)$ is allowed'.

\begin{tabular}{lllll}
\hline & Weak teaching & Weak learning & Strong teaching & Strong learning \\
\hline heqe ̌́ & - & for $\mathrm{g}$ & for $\mathrm{q}$ & - \\
gezerah šawah & for $\mathrm{h}$ & - & for $\mathrm{q}$ & - \\
qal wa-homer & - & - & - & for $\mathrm{g}$, for $\mathrm{h}$ \\
\multicolumn{2}{l}{ Does qal wa-ḥomer have a strong teaching for qal wa-homer? } & & \\
\hline
\end{tabular}


Since $\mathrm{g}$ is weaker than $\mathrm{q}$ (because $\mathrm{g}$ is a weak teaching for $\mathrm{h}$, but $\mathrm{q}$ is a strong learning for $\mathrm{h}$ ) and $\mathrm{g}$ has the property to be a strong teaching for $\mathrm{q}$. From minor to major we obtain that $\mathrm{q}$ has the property of $\mathrm{g}$ to be a strong teaching for $\mathrm{q}$.

Q6 If a heqeš, which cannot be learnt through a heqeš (1), can teach by a qal wahomer and a qal wa-homer is learnt through a heqeš (6), then this qal wa-homer can surely teach through a qal wa-homer:

$$
\begin{aligned}
& \left({ }^{\prime} \operatorname{Der}^{\mathrm{h}}\left(A, \operatorname{Der}^{\mathrm{h}}(B, Y)\right) \text { is rejected' } \&{ }^{\prime} \operatorname{Der}^{\mathrm{q}}\left(C, \operatorname{Der}^{\mathrm{h}}(A, X)\right)\right. \text { is allowed' \& } \\
& \left.\operatorname{DDer}^{\mathrm{q}}\left(D, \operatorname{Der}^{\mathrm{h}}(B, Y)\right) \text { is allowed' }\right) \Rightarrow{ }^{\prime} \operatorname{Der}^{\mathrm{q}}\left(E, \operatorname{Der}^{\mathrm{q}}(D, Z)\right) \text { is allowed'. }
\end{aligned}
$$

\begin{tabular}{lllll}
\hline & weak teaching & weak learning & strong teaching & strong learning \\
\hline heqě̌ & for h & for $\mathrm{h}$ & for $\mathrm{q}$ & - \\
gezerah šawah & - & - & - & for $\mathrm{h}$ \\
qal wa-homer & - & - & - & - \\
Does qal wa-ḥomer & have a strong learning for qal wa-homer? & & \\
\hline
\end{tabular}

We know that $\mathrm{h}$ is weaker than $\mathrm{q}$ (indeed, $\mathrm{h}$ is a weak learning for $\mathrm{h}$, but $\mathrm{q}$ is a strong learning for $\mathrm{h}$ ) and $\mathrm{h}$ has the property to be a strong teaching for $\mathrm{q}$. From minor to major we infer that $\mathrm{q}$ has the property of $\mathrm{h}$ to be a strong teaching for $\mathrm{q}$.

Reasoning from Q1 to Q6 shows that heqes is the weakest inference rule and qal wa-homer the strongest. As we see, in the Talmudic inference rules have different pragmatic limits within the subject of the realm of the sacred. The widest limits are borne by qal wa-homer that can be applied everywhere, the most restricted by heqeř.

The Talmudic reasoning in Zevachim 49b-51a tells us about pragmatic aspects of logical inference rules involved for inferring Judaic laws. It is prohibited to use inference rules without regarding these aspects. For example, we cannot use a heqe $\breve{s}$ in one and the same deduction if we face cases (1)-(4). According to these aspects, many Judaic proofs may be drawn up only as parallel processes.

The Judaic argumentation theory also contains pragmatic limits for proofs as competitive communication when different Rabbis claim different opinions in respect to the same subject. In order to define these limits we build up a special kind of syllogistics where it is defined whose opinion should be choosen in a dispute. This system is called Judaic pragmatic-syllogistics. While the logical analysis of Zevachim 49b-51a concernes how the topic of Talmudic discussion (e.g. the realm of the sacred) determines restrictions in deducing, Judaic pragmatic-syllogistics shows whose opinions we should follow in Talmudic discussions as such.

Definition 6 The alphabet of Judaic pragmatic-syllogistics is an ordered system $\mathbf{A}_{P}=\left\langle V, Q_{1}, Q_{2}, L_{1}, L_{2}, L_{3}, L_{4}, K\right\rangle$, where

1. $V$ is the set of propositional variables $p, q, r, \ldots$;

2. $Q_{1}$ is a set of pragmatic-syllogistic variables $P, Q, R, \ldots$ running over different sages (Tannaim as well as Amoraim);

3. $Q_{2}$ is a set of pragmatic-syllogistic constants including the following 28 sages: 
Mar bar Rav 'Aši [מר בר רב אשי], the sage of Babylon, Amora of the seventh generation, the son of Rav 'Aši, he headed the academy of Sura city.

Rab [רבי אבא אריכא], the Amora of the first generation, who lived in Babylonia, where he established an academy at Sura.

Rabbah [רבה בר נחמני], the sage of Babylon, Amora of the third generation.

Rabban Sim'on ben Gamli'el [רבן שמעון בן גמליאל], the Tanna of the third generation and president of the Great Sanhedrin, the father of Rabbi Yehudah haNaśi'.

Rabbi 'Eli'ezer [בן הורקנוס רבי אליעזר], the Israelite, the Tanna of the second generation, he descended from a priestly family.

Rabbi 'Eli'ezer ben Ya'qob [רבי אליעזר בן יעקב], the Tanna of the fourth generation, the student of Rabbi 'Akiba'.

Rabbi Gamali'el [רבי גמליאל דיבנה], the Israelite, the Tanna of the second generation, the first person to lead the Sanhedrin as president after the fall of the second temple.

Rabbi Hiyy'a רבי חייא], the Israelite, the Amora belonging to the first generation.

Rabbi Me'ir [רבי מאיר], the Tanna of the fourth generation, his father was a descendant of the Roman Emperor Nero who had converted to Judaism.

Rabbi Natan [רבי נתן הבבלי], the Tanna of the third generation, the son of a Babylonian exilarch, then he settled in the land of Israel, where he was made chief of the school at Usha.

Rabbi Nehemiah [רבי נחמיה], the Israelite, the Tanna of the fourth generation, attributed as the author of the Mišnat ha-Middot, the earliest known Hebrew text on geometry.

Rabbi Šm'on [רבי שמעון בר יוחאי], the Israelite, the Tanna of the fourth generation, attributed as the author of the Zohar, the chief work of Kabbalah, he was also one of the most eminent disciples of Rabbi 'Akiba'.

Rabbi Šim'on ben 'Ele'azar [רבי שמעון בן אלעזר], the Tanna of the fourth generation, the student of Rabbi Me'ir.

Rabbi Yehošu'a רבי יהושע בן חנניה], the Israelite, the Tanna of the second generation, the Levitical descent, he served in the sanctuary as a member of the class of singers.

Rabbi Yehudah [רבי יהודה בר מערבא], the Israelite, the Tanna of the fourth

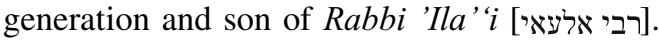

Rabbi Yehudah ha-Naśi' [רבי יהודה הנשיאי], the Israelite, the Tanna of the fifth generation, the chief editor of the Mishnah, he was of the royal line of King David.

Rabbi Yisma' 'el [רבי ישמעאל], the Israelite, the Tanna of the third generation, he formalized a set of 13 hermeneutic rules by which halakha was derived from the Torah.

Rabbi Yose [רבי יוסי בן חלפתא], the Israelite, the Tanna of the fourth generation, the student of Rabbi 'Akiba'.

Rav 'Aha' [רבי אחא], the Israelite, Amora of the fourth generation.

Rav 'Aš [רב אשי], the Babylonian Amora of the sixth generation, one the first editors of the Babylonian Talmud, he reestablished the academy at Sura.

Rav Hisda' [רב חסדא], the Babylonian Amora of the third generation, he descended from a priestly family, the disciple of Rav and Rav Huna'. 
Rav Huna' רב הונא], the Amora of the second generation who lived in Babylonia and headed the academy of Sura, the disciple of Rav, he descended from a priestly family.

Rav Nahman [רב נחמן בר יעקב, the Amora of the third generation, who lived in Babylonia, the student of Šmu'el and then the head of the school of Nehardea.

Rav Šešet [רב ששת], the Babylonian Amora of the third generation and colleague of Rav Nahman.

Rav Yehudah [רב יהודה בן יחזקאל], the Babylonian Amora of the second generation, the disciple of Rav, he founded an academy at Pumbedita.

Rav Yosef [רב יוסף בר חייא], the Amora of the third generation, who lived in Babylonia, the disciple of Rav Yehudah, the head of the academy of Pumbedita.

Ravina' [רבינא], the Babylonian Amora of the sixth generation, one of the first editors of the Babylonian Talmud.

Šmu'el [שמואל], one of the leading Babylonian Amoraim of the first generation, who succeeded his father as head of the academy of Nehardea, he mastered the contemporary sciences such as medicine and astronomy.

4. $L_{1}=\{\neg\}$;

5. $L_{2}=\{\wedge, \vee, \Rightarrow\}$;

6. $L_{3}$ is a set containing two unary pragmatic-syllogistic connectives $\mathrm{A}(\ldots), \mathrm{H}$ (...) meaning "the statement... is anonymous," "... is the final decision (halakha)" respectively;

7. $L_{4}$ is a set of binary pragmatic-syllogistic connectives containing five elements $\ldots={ }_{b} \ldots, \mathrm{T}(\ldots, \ldots), t(\ldots, \ldots), \ldots * \ldots, \operatorname{exc}_{n}(\ldots)$ called the functors "the statement... belongs to the sage ...," "the sage... is a disciple of the sage ...," "the sage... is later than the sage ...," "the statement ... is followed by the statement...," "the opinion of the sage ... prevails (or is rejected), but not in these $n$ named cases" respectively.

8. $L_{5}$ is a set consisting of the only ternary pragmatic-syllogistic connective agst .........) called the functor "in respect to the statement... the sage ... is against the sage ..."

9. $K$ is the set of auxiliary symbols containing two brackets:(,).

Definition 7 The language of Judaic pragmatic-syllogistics is an ordered system $\mathbf{L}_{P}=\left\langle\mathbf{A}_{P}, \mathbf{F}_{P}\right\rangle$, where

1. $\mathbf{A}_{P}$ is the alphabet of Judaic pragmatic-syllogistics;

2. $\mathbf{F}_{P}$ is a set of all formulas formed by means of symbols in $\mathbf{A}_{P}$; this set $\mathbf{F}_{P}$ contains all formulas defined by the standard rules defining well-formed propositional formulas and additionally by the following rules:

(d1) if $\varphi$ is propositional formula, then the expression $\mathrm{A}(\varphi)$ is a formula of pragmatic-syllogistics;

(d2) if $\varphi$ is propositional formula, then the expression $\mathrm{H}(\varphi)$ is a formula of pragmatic-syllogistics;

(d3) if $\varphi$ is a propositional formula and $Q$ is a pragmatic-syllogistic variable (or a pragmatic-syllogistic constant), then the expression $\varphi={ }_{b} Q$ is a formula of pragmatic-syllogistics;

(d4) if $P, Q$ are pragmatic-syllogistic variables (or pragmatic-syllogistic constants), then the expression $\mathrm{T}(P, Q)$ is a formula of pragmatic-syllogistics; 
(d5) if $P, Q$ are pragmatic-syllogistic variables (or pragmatic-syllogistic constants), then the expression $t(P, Q)$ is a formula of pragmatic-syllogistics;

(d6) if $\varphi, \psi$ are propositional formulas, then the expression $\varphi^{*} \psi$ is a formula of pragmatic-syllogistics;

(d7) if $Q$ is a pragmatic-syllogistic variable (or a pragmatic-syllogistic constant), then the expression $\operatorname{exc}_{n}(Q)$ is a formula of pragmatic-syllogistics;

(d8) if $\varphi$ is propositional formula and $P, Q$ are pragmatic-syllogistic variables (or pragmatic-syllogistic constants), then the expression $\operatorname{agst}_{\varphi}(P, Q)$ is a formula of pragmatic-syllogistics.

Formulas that are defined by means of rules (d1)-(d8) are called formulas of Judaic pragmatic-syllogistics in the strict sense. They are denoted by P.

Definition 8 Judaic pragmatic-syllogistics is an ordered system $\mathbf{S}_{P}=\left\langle\mathbf{A}_{P}, \mathbf{F}_{P}, C\right\rangle$, where

1. $\mathbf{A}_{P}$ is the alphabet of Judaic pragmatic-syllogistics;

2. $\mathbf{F}_{P}$ is a set of all formulas formed by means of symbols in $\mathbf{A}_{P}$;

3. $C$ is the inference operation in $\mathbf{F}_{P}$.

The inference rules of Judaic pragmatic-syllogistics are as follows:

1. the substitution rule, we replace a propositional variable $p_{j}$ of formula $\alpha\left(p_{1}, \ldots\right.$, $\left.p_{n}\right)$, containing propositional variables $p_{1}, \ldots, p_{n}$, by a propositional formula $\beta\left(q_{1}, \ldots\right.$, $q_{k}$ ), containing propositional variables $q_{1}, \ldots, q_{k}$ (as well as by a pragmatic-syllogistic formula $\beta(\sigma, \tau)$ or $\beta(\sigma)$ ), containing pragmatic-syllogistic variables or pragmaticsyllogistic constants), and we obtain a new propositional formula $\alpha^{\prime}\left(p_{1}, \ldots, p_{j-1}\right.$, $\left.\beta\left(q_{1}, \ldots, q_{k}\right), \quad p_{j+1}, \ldots, p_{n}\right)$ (as well as a new pragmatic-syllogistic formula $\alpha^{\prime}\left(p_{1}, \ldots, p_{j-1}, \beta(\sigma, \tau), p_{j+1}, \ldots, p_{n}\right)$ or $\left.\alpha^{\prime}\left(p_{1}, \ldots, p_{j-1}, \beta(\sigma), p_{j+1}, \ldots, p_{n}\right)\right)$ :

$$
\frac{\alpha\left(p_{1}, \ldots, p_{j}, \ldots, p_{n}\right)}{\alpha^{\prime}\left(p_{1}, \ldots, p_{j-1}, \beta\left(q_{1}, \ldots, q_{k}\right), p_{j+1}, \ldots, p_{n}\right)}
$$

or

$$
\frac{\alpha\left(p_{1}, \ldots, p_{j}, \ldots, p_{n}\right)}{\alpha^{\prime}\left(p_{1}, \ldots, p_{j-1}, \beta(\sigma, \tau), p_{j+1}, \ldots, p_{n}\right)}, \frac{\alpha\left(p_{1}, \ldots, p_{j}, \ldots, p_{n}\right)}{\alpha^{\prime}\left(p_{1}, \ldots, p_{j-1}, \beta(\sigma), p_{j+1}, \ldots, p_{n}\right)}
$$

In the same way, from any pragmatic-syllogistic formula $\beta(p, P), \beta(p), \beta(P, Q)$, $\operatorname{agst}_{p}(P, Q)$ or $\beta(P)$ a new formula $\beta^{\prime}\left(\alpha\left(q_{1}, \ldots, q_{k}\right), P\right), \beta^{\prime}\left(\alpha\left(q_{1}, \ldots, q_{k}\right)\right), \beta^{\prime}(R, Q)$, $\beta^{\prime}(P, R), \operatorname{agst}_{\alpha\left(q_{1}, \ldots, q_{k}\right)}(P, Q)$, agst $(R, Q)$, $\operatorname{agst}_{p}(P, R)$ or $\beta^{\prime}(R)$ follows if we replace a propositional variable $p$ by a propositional formula $\alpha\left(q_{1}, \ldots, q_{k}\right)$, containing propositional variables $q_{1}, \ldots, q_{k}$, or a pragmatic-syllogistic variable $P$ by $R$ and $Q$ by $R$ :

$$
\begin{array}{cccc}
\frac{\beta(p, P)}{\beta^{\prime}\left(\alpha\left(q_{1}, \ldots, q_{k}\right), P\right)}, & \frac{\beta(p)}{\beta^{\prime}\left(\alpha\left(q_{1}, \ldots, q_{k}\right)\right)}, & \frac{\beta(P, Q)}{\beta^{\prime}(R, Q)}, & \frac{\beta(P, Q)}{\beta^{\prime}(P, R)}, \\
\frac{\operatorname{agst}_{p}(P, Q)}{\operatorname{agst}_{\alpha\left(q_{1}, \ldots, q_{k}\right)}(P, Q)}, & \frac{\operatorname{agst}_{p}(P, Q)}{\operatorname{agst}_{p}(R, Q)}, & \frac{\operatorname{agst}_{p}(P, Q)}{\operatorname{agst}_{p}(P, R)}, & \frac{\beta(P)}{\beta^{\prime}(R)}
\end{array}
$$

2. modus ponens, according to that if two formulas of pragmatic-syllogistics $\alpha$ and $\alpha \Rightarrow \beta$ hold, then we deduce a formula $\beta$. 
Now let us consider the axioms Judaic of pragmatic-syllogistics. First of all, they consist of axioms of propositional logic, and furthermore of the following additional expressions:

The axioms concerning the general properties to be a conflict between sages:

$$
\begin{gathered}
\operatorname{agst}_{\varphi}(Q, Q), \\
\operatorname{agst}_{\varphi}(Q, R) \Rightarrow \operatorname{agst}_{\varphi}(R, Q), \\
\operatorname{agst}_{\varphi}(Q, R) \Rightarrow\left(\varphi={ }_{b} Q \vee \varphi={ }_{b} R\right), \\
\operatorname{agst}_{\varphi}(Q, R) \Rightarrow\left(\varphi={ }_{b} Q \Rightarrow \neg\left(\varphi={ }_{b} R\right)\right), \\
\left((\phi \equiv \neg \psi) \wedge \varphi={ }_{b} Q \wedge\left(\psi={ }_{b} R\right)\right) \Rightarrow \operatorname{agst}_{\varphi}(Q, R), \\
A(\varphi) \Rightarrow \neg \operatorname{agst}_{\varphi}(Q, R) .
\end{gathered}
$$

The axioms concerning the general properties to be a teacher of another sage:

$$
\begin{gathered}
\neg \mathrm{T}(Q, Q), \\
\mathrm{T}(Q, R) \Rightarrow \neg \mathrm{T}(R, Q), \\
(\mathrm{T}(P, Q) \wedge \mathrm{T}(Q, R)) \Rightarrow \mathrm{T}(P, R), \\
\left(\varphi={ }_{b} P \wedge \neg \operatorname{agst}_{\varphi}(P, Q) \wedge \mathrm{T}(P, Q)\right) \Rightarrow \varphi={ }_{b} Q .
\end{gathered}
$$

The axioms in respect to the general properties to be later than another sage:

$$
\begin{gathered}
\neg t(Q, Q), \\
t(Q, R) \Rightarrow \neg t(R, Q), \\
(t(P, Q) \wedge t(Q, R)) \Rightarrow t(P, R) .
\end{gathered}
$$

The general properties to be followed by another statement are expressed by the following axioms:

$$
\begin{gathered}
\neg(\varphi * \varphi), \\
(\varphi * \psi) \Rightarrow \neg(\psi * \varphi), \\
(\varphi * \psi) \wedge(\psi * \chi) \Rightarrow(\varphi * \chi) .
\end{gathered}
$$

The general properties to be an opinion of a sage are formulated by the axioms:

$$
\left(\psi={ }_{b} Q \wedge(\varphi \Rightarrow \psi)\right) \Rightarrow \varphi={ }_{b} Q,
$$




$$
\begin{gathered}
\varphi={ }_{b} Q \Rightarrow \neg\left(\neg \varphi={ }_{b} Q\right), \\
(\phi \wedge \psi)={ }_{b} Q \Rightarrow\left(\left(\varphi={ }_{b} Q\right) \wedge\left(\varphi={ }_{b} Q\right)\right) .
\end{gathered}
$$

The axioms regarding the general properties to be a final decision (halakhah):

$$
\begin{gathered}
(\mathrm{H}(\psi) \wedge(\varphi \Rightarrow \psi)) \Rightarrow \mathrm{H}(\varphi), \\
\mathrm{H}(\varphi) \Rightarrow \neg(\mathrm{H}(\neg \varphi)), \\
\mathrm{H}(\varphi \wedge \psi) \equiv(\mathrm{H}(\varphi) \wedge \mathrm{H}(\psi)) .
\end{gathered}
$$

The next axioms describing more specific properties of pragmatic-syllogistic connectives were formulated by Rabbi Samuel ha-Nagid, the Spanish poet and Talmudist, born at Cordova 993 and died at Granada 1055, in his famous book, the Introduction to the Talmud [מבוא התלמוד]. These axioms are compiled by him from the Talmud and completely accepted in Judaism.

D1 One sage against many: the final decision is like the many, i.e. when the opinion of an individual conflicted with that of the majority, we should choose the opinion of the majority:

$$
\begin{gathered}
\left(\neg\left(\varphi={ }_{b} Q\right) \wedge \varphi={ }_{b} R_{1} \wedge \varphi={ }_{b} R_{2} \wedge \cdots \wedge \varphi={ }_{b} R_{n}\right) \wedge \\
\left(\operatorname{agst}_{\varphi}\left(Q, R_{1}\right) \wedge \operatorname{agst}_{\varphi}\left(Q, R_{2}\right) \wedge \cdots \wedge \operatorname{agst}_{\varphi}\left(Q, R_{n}\right)\right) \Rightarrow H(\varphi) .
\end{gathered}
$$

D2 The final decision is never like the disciple when in dispute with his teacher:

$$
\left(\varphi={ }_{b} Q \wedge T(Q, R) \wedge \operatorname{agst}_{\varphi}(Q, R)\right) \Rightarrow \neg H(\varphi) .
$$

D3 If a later sage is in dispute with an earlier sage, the final decision is like the later sage:

$$
\left(\varphi={ }_{b} Q \wedge t(Q, R) \wedge \operatorname{agst}_{\varphi}(Q, R)\right) \Rightarrow H(\varphi) .
$$

D4 Within one tractate of the Mishnah, a dispute followed by an anonymous statement, representing one of the views, means that the final decision is in accordance with the latter:

$$
\left(\varphi * \psi \wedge(\varphi \equiv \neg \psi) \wedge \operatorname{agst}_{\varphi}(Q, R) \wedge A(\psi)\right) \Rightarrow H(\psi) .
$$

D5 Within one tractate of the Mishnah, an anonymous statement followed by statements containing a dispute means that the final decision is not like the anonymous statement:

$$
\left(\varphi * \psi \wedge(\varphi \equiv \neg \psi) \wedge \operatorname{agst}_{\psi}(Q, R) \wedge A(\varphi)\right) \Rightarrow \neg H(\varphi) .
$$

D6 If there is a dispute in the Barayta and an anonymous statement in the Mishnah following one view, the final decision is like the latter:

$\left(\varphi\right.$ from the Barayta $\wedge \psi$ from the Mishnah $\wedge(\varphi \equiv \neg \psi) \wedge$ agst $_{\varphi}(Q, R)$

$$
\wedge A(\psi)) \Rightarrow H(\psi) \text {. }
$$


D7 If there is a dispute in the Mishnah and an anonymous statement in the Barayta, we do not say the final decision is like the Barayta, because we say "If Rabbi Yehudah ha-Naśi' did not teach it, how could Rabbi Hiyy'a, the editor of the Barayta, know it?"

$\left(\varphi\right.$ from the Barayta $\wedge \psi$ from the Mishnah $\wedge(\varphi \equiv \neg \psi) \wedge$ agst $\left._{\psi}(Q, R) \wedge A(\varphi)\right)$ $\Rightarrow \neg H(\varphi)$.

D8 The compilers of the Talmud were Rav 'Aši and Ravina' and their colleagues:

( $\varphi$ from the Gemara $\wedge A(\varphi)) \Rightarrow\left(\varphi={ }_{b}\right.$ Rav'Asi $\vee \varphi={ }_{b}$ Ravina').

D9 An anonymous statement in the Mishnah belongs to Rabbi Me'ir:

$$
\text { ( } \varphi \text { from the Mishnah } \wedge A(\varphi)) \Rightarrow\left(\varphi={ }_{b} \text { Rabbi Me'ir }\right) .
$$

D10 An anonymous statement in the Tosefta belongs to Rabbi Ne hemiah:

( $\varphi$ from the Tosefta $\wedge A(\varphi)) \Rightarrow\left(\varphi={ }_{b}\right.$ Rabbi Nehemiah $)$.

D11 An anonymous statement in the Sifra belongs to Rabbi Yehudah:

$$
\text { ( } \varphi \text { from the Sifra } \wedge A(\varphi)) \Rightarrow\left(\varphi={ }_{b} \text { Rabbi Yehudah }\right) \text {. }
$$

D12 An anonymous statement in the Sifre belongs to Rabbi Sim 'on:

( $\varphi$ from the Sifre $\wedge A(\varphi)) \Rightarrow\left(\varphi={ }_{b}\right.$ Rabbi Sim'on $)$.

Notice that by using axioms (12), (16), D12, we can prove that if the statement $\varphi$ from the Sifre is anonymous, then it belongs to Rabbi 'Akiba', because Rabbi Šm 'on is a disciple of Rabbi 'Akiba'.

D13 “Some say" [יש אומרים] means Rabbi Natan:

$$
\text { "Some say } \varphi \text { " } \Rightarrow \varphi={ }_{b} \text { Rabbi Natan. }
$$

D14 “Others say" [אחרים אומרים] means Rabbi Me’ir:

$$
\text { “'Other say } \varphi \text { " } \Rightarrow \varphi={ }_{b} \text { Rabbi Me'ir. }
$$

D15 Where Rabbi Me'ir is named in a source, and his decision is disputed, either by Rabbi Yehudah, Rabbi Yose, Rabbi Šim 'on or Rabbi 'Eli 'ezer ben Ya'qob, the final decision is like his opponent:

$$
\begin{aligned}
& \left(\varphi={ }_{b} \text { Rabbi Yehudah } \wedge \operatorname{agst}_{\varphi}(\text { Rabbi Me'ir, Rabbi Yehudah })\right) \Rightarrow \mathrm{H}(\varphi), \\
& \left(\varphi={ }_{b} \text { Rabbi Yose } \wedge \operatorname{agst}_{\varphi}(\text { Rabbi Me'ir, Rabbi Yose })\right) \Rightarrow \mathrm{H}(\varphi), \\
& \left(\varphi={ }_{b} \text { Rabbi Šim 'on } \wedge \operatorname{agst}_{\varphi}(\text { Rabbi Me'ir, Rabbi Sim 'on })\right) \Rightarrow \mathrm{H}(\varphi), \\
& \left(\varphi={ }_{b} \text { Rabbi 'Eli'ezer ben Ya'qob } \wedge \text { agst }_{\varphi}(\text { Rabbi Me'ir, Rabbi 'Eli'ezer ben }\right. \\
& \text { Ya'qob) }) \stackrel{\Rightarrow}{\Rightarrow}(\varphi) .
\end{aligned}
$$


D16 Rabbi Yehudah against Rabbi Šim'on: the final decision is like Rabbi Yehudah:

$\left(\varphi={ }_{b}\right.$ Rabbi Yehudah $\wedge \operatorname{agst}_{\varphi}($ Rabbi Sim 'on, Rabbi Yehudah $\left.)\right) \Rightarrow H(\varphi)$.

D17 The final decision is always like Rabbi Yose, even against more than one named Tanna:

$$
\left(\varphi={ }_{b} \text { Rabbi Yose } \wedge \operatorname{agst}_{\varphi}(\text { Rabbi Yose }, Q)\right) \Rightarrow H(\varphi) .
$$

D18 The Mishnah of Rabbi 'Eli'ezer ben Ya'qob is "small but pure" [משנת ראב"י קב ונקי], i.e. he is not mentioned often, but when he is the final decision is always like him:

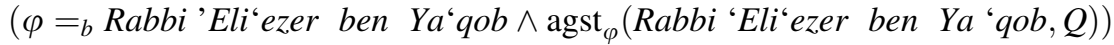

$$
\begin{aligned}
& \Rightarrow H(\varphi) \text {. }
\end{aligned}
$$

D19 Rabbi Yehudah ha-Naśi against Rabbi Šim'on ben 'Ele'azar: the final decision is like Rabbi Yehudah ha-Naśi:

$\left(\varphi={ }_{b}\right.$ Rabbi Yehudah ha-Naśi' $\wedge \operatorname{agst}_{\varphi}($ Rabbi Yehudah ha-Naśi', Rabbi Šm 'on ben 'Ele 'azar $)) \Rightarrow \mathrm{H}(\varphi)$.

D20 Rabbi Yehudah ha-Naśi' against Rabbi Yehudah: the final decision is like Rabbi Yehudah ha-Nasí':

$\left(\varphi={ }_{b}\right.$ Rabbi Yehudah ha-Naśi' $\wedge$ agst $_{\varphi}($ Rabbi Yehudah ha-Naśi', Rabbi Yehudah $)) \Rightarrow \mathrm{H}(\varphi)$

D21 Rabbi Yehudah ha-Naśi' against Rabbi Me 'ir: the final decision is like Rabbi Yehudah ha-Naśi':

$\left(\varphi={ }_{b}\right.$ Rabbi Yehudah ha-Naśi' $\wedge$ agst $_{\varphi}($ Rabbi Yehudah ha-Naśi', Rabbi $\left.\left.M e^{\prime} i r\right)\right) \Rightarrow \mathrm{H}(\varphi)$.

D22 Rabbi Yehudah ha-Naśi' against Rabbi Yose in words of Rabbi Yehudah: the final decision is like Rabbi Yehudah ha-Naśi':

$\left(\varphi={ }_{b}\right.$ Rabbi Yehudah ha-Naśi' $\wedge$ agst $_{\varphi}($ Rabbi Yehudah ha-Naśi', Rabbi Yose in words of Rabbi Yehudah)) $\Rightarrow \mathrm{H}(\varphi)$.

D23 Rabbi Yehudah ha-Naśi' against Rabbi Yisma' 'el in words of Rabbi Yose: the final decision is like Rabbi Yehudah ha-Naśi':

$\left(\varphi={ }_{b}\right.$ Rabbi Yehudah ha-Naśi' $\wedge$ agst $_{\varphi}($ Rabbi Yehudah ha-Naśi', Rabbi Yišma' $e l$ in words of Rabbi Yose $)) \Rightarrow \mathrm{H}(\varphi)$.

This condition that Rabbi Yehudah ha-Naśi' is not against Rabbi Yišma' el directly because of the restriction defined in D2, D3.

D24 Rabbi Yehudah ha-Naśi' against Rabban Šim 'on ben Gamli'el: the final decision is like Rabban Šim 'on ben Gamli'el: 
$\left(\varphi={ }_{b}\right.$ Rabban Šim 'on ben Gamli'el $\wedge \operatorname{agst}_{\varphi}($ Rabbi Yehudah ha-Naśi', Rabban

Sim 'on ben Gamli'el) $\Rightarrow \mathrm{H}(\varphi)$.

From this statement, we can assume that Rabbi Yehudah ha-Naśi' is a disciple of Rabban Šim 'on ben Gamli'el, taking into account D2.

D25 Wherever Rabban Sim 'on ben Gamli'el appears in the Mishnah and there is no dispute, the final decision is like him:

$$
\begin{aligned}
& \left(\varphi={ }_{b} \text { Rabban Sim'on ben Gamli'el } \wedge \neg \operatorname{agst}_{\varphi}(\text { Rabban Sim 'on ben Gamli' el, } Q)\right) \\
& \quad \Rightarrow H(\varphi) .
\end{aligned}
$$

D26 Rabbi 'Eli'ezer against Rabbi Yehošu'a: the final decision is like Rabbi Yehoั̌u' $a$ :

$$
\left(\varphi={ }_{b} \text { Rabbi Yehošu'a } \wedge \operatorname{agst}_{\varphi}(\text { Rabbi 'Eli'ezer, Rabbi Yehošu'a })\right) \Rightarrow \mathrm{H}(\varphi) .
$$

D27 Rabbi 'Eli 'ezer against Rabbi Gamali'el: the final decision is like Rabbi Gamali'el:

$$
\left(\varphi={ }_{b} \text { Rabbi Gamali' el } \wedge \operatorname{agst}_{\varphi}\left(\text { Rabbi }^{\prime} \text { Eli'ezer, Rabbi Gamali' } e l\right)\right) \Rightarrow H(\varphi) .
$$

D28 Wherever Rabban Šm 'on ben Gamli'el appears in the Mishnah the final decision is like him, except in four named cases:

$\left(\varphi={ }_{b}\right.$ Rabban Šim 'on ben Gamli'el $\wedge \operatorname{agst}_{\varphi}($ Rabban Šim 'on ben Gamli'el, $\left.Q)\right)$ $\Rightarrow\left(\mathrm{H}(\varphi) \vee\left(\operatorname{exc}_{4}(\right.\right.$ Rabban Šim 'on ben Gamli'el $\left.\left.) \Rightarrow \varphi\right)\right)$.

D29 The final decision does not follow the disciples of Rabbi 'Eli 'ezer, except in eight named cases:

$$
\left(\varphi={ }_{b} Q \wedge \mathrm{T}\left(Q, \text { Rabbi }^{\prime} \text { Eli }^{\prime} \text { ezer }\right) \wedge \operatorname{agst}_{\varphi}(Q, R)\right) \Rightarrow\left(\neg H(\varphi) \vee\left(\operatorname{exc}_{8}(Q) \Rightarrow \varphi\right)\right) .
$$

D30 Shammai's party against Hillel's party: the halacha is like Hillel's party, except in six named cases of Hillel's party and in three named cases of Shammai's party:

$$
\begin{aligned}
(\varphi & \left.={ }_{b} Q \wedge \mathrm{T}(Q, \text { Hillel }) \wedge \mathrm{T}(R, \text { Shammai }) \wedge \operatorname{agst}_{\varphi}(Q, R)\right) \\
& \Rightarrow\left(H(\varphi) \vee\left(\operatorname{exc}_{6}(Q) \Rightarrow \varphi\right) \vee\left(\operatorname{exc}_{3}(R) \Rightarrow \varphi\right)\right)
\end{aligned}
$$

D31 $R a b$ against $\breve{S} m u$ 'el: the final decision is like $R a b$ in prohibitions and like Šmu'el in laws:

$$
\begin{aligned}
& \left(\varphi={ }_{b} \check{S} m u^{\prime} e l \wedge \neg \psi={ }_{b} R a b \wedge \operatorname{agst}_{\varphi}\left(R a b, S^{\prime} m u^{\prime} e l\right) \wedge \operatorname{agst}_{\neg \psi}\left(R a b, \breve{S} m u^{\prime} e l\right)\right) \Rightarrow \\
& (\mathrm{H}(\varphi) \wedge \mathrm{H}(\neg \psi)) .
\end{aligned}
$$

D32 Rav Hisda' against Rav Huna': the final decision is like Rav Huna':

$$
\left(\varphi={ }_{b} \text { Rav Huna'^ } \operatorname{agst}_{\varphi}(\text { Rav Huna', Rav Hisda' })\right) \Rightarrow \mathrm{H}(\varphi) .
$$


D33 Rav Šešet against Rav Nahman: the final decision is like Rav Šešet in prohibitions and like Rav Naḥman in laws:

$\left(\varphi={ }_{b}\right.$ Rav Naḥman $\wedge \neg \psi={ }_{b}$ Rav Šešet $\wedge \operatorname{agst}_{\varphi}($ Rav Šěset, Rav Nahman $) \wedge$

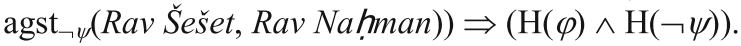

D34 Rav Yehudah against Rabbah: the final decision is like Rav Yehudah:

$$
\left(\varphi={ }_{b} \text { Rav Yehudah } \wedge \operatorname{agst}_{\varphi}(\text { Rav Yehudah, Rabbah })\right) \Rightarrow H(\varphi) .
$$

D35 Rabbah against Rav Yosef: the final decision is like Rabbah, except in three named cases:

$$
\left(\varphi={ }_{b} \operatorname{Rabbah} \wedge \operatorname{agst}_{\varphi}(\text { Rabbah, Rav Yosef })\right) \Rightarrow\left(H(\varphi) \vee\left(\operatorname{exc}_{3}(\text { Rabbah }) \Rightarrow \varphi\right) .\right.
$$

D36 Rav'Aha' against Ravina': the final decision is like Ravina', except in three named cases:

$$
\left(\varphi={ }_{b} \text { Ravina' }^{\prime} \wedge \operatorname{agst}_{\varphi}\left(\text { Ravina'}^{\prime}, \text { Rav' }^{\prime} A h a^{\prime}\right)\right) \Rightarrow\left(H(\varphi) \vee\left(\operatorname{exc}_{3}\left(\text { Ravina' }^{\prime}\right) \Rightarrow \varphi\right) .\right.
$$

D37 The final decision is like Mar bar Rav'Asi except where he is in dispute with Rav 'Aši:

$\left(\varphi={ }_{b} \operatorname{Mar} \operatorname{bar} \operatorname{Rav}{ }^{\prime} A \check{s} i \wedge \neg\left(Q \equiv \operatorname{Rav}^{\prime} A \check{s} i\right) \wedge \operatorname{agst}_{\varphi}\left(\operatorname{Mar} \operatorname{bar} \operatorname{Rav}{ }^{\prime} A \check{s} i, Q\right)\right) \Rightarrow$ $\mathrm{H}(\varphi)$;

$$
\left(\varphi={ }_{b} \operatorname{Rav}{ }^{\prime} A \check{s} i \wedge \operatorname{agst}_{\varphi}\left(\operatorname{Rav}{ }^{\prime} A \check{s} i, \text { Mar bar Rav 'Ǎsi }\right)\right) \Rightarrow \mathrm{H}(\varphi) .
$$

This additional axiom is needed because Rav' Aši is his teacher (see D2, D3). Models for Judaic pragmatic-syllogistics is defined as follows:

Definition 9 A structure $\mathbf{M}=\left\langle O=\left\{\dot{O}: \dot{O} \in Q_{2}\right\} I, \dot{\mathrm{A}}, \dot{\mathrm{H}}, \dot{=}_{b}, \dot{\mathrm{T}}, \dot{t}, \dot{*}\right.$, exc $_{n}$, agst $\rangle$ is a Judaic pragmatic-syllogistic model iff:

1. $O$ is the set of objects including 28 sages named above.

2. I associates each connective $o \in\left\{A, H,=_{b}, \mathrm{~T}, t, *\right.$, $\operatorname{exc}_{n}$, agst $\}$ over formulas of P with an appropriate connective $\dot{o} \in\left\{\dot{\mathrm{A}}, \dot{\mathrm{H}}, \dot{\bar{~}}_{h}, \dot{\mathrm{T}}, \dot{t}, \dot{*}\right.$, ex $\mathrm{c}_{n}$, a $\left.\dot{\mathrm{g} s t}\right\}$.

3. $\dot{A}$ is a mapping from $\mathbf{F} / \Leftrightarrow$ onto $\{0,1\}$ satisfying conditions (12), D7-D12.

4. $\dot{\mathrm{H}}$ is a mapping from $\mathbf{F} / \Leftrightarrow$ onto $\{0,1\}$ satisfying conditions (26), (27), (28), D1-D7, D15-D37.

$5 .{ }_{b}$ is a relation on $(\mathbf{F} / \Leftrightarrow) \times O$ satisfying conditions (9), (10), (11), (16), (23)(25), D1, D2, D3, D8-D37.

6. $\dot{\mathrm{T}}$ is a quasi (less-than) relation on $O \times O$ satisfying the conditions (13)-(16), D2, D29, D30.

7. $\dot{t}$ is a quasi (less-than) relation on $O \times O$ satisfying the conditions (17)-(19), D3.

$8 . \dot{*}$ is a quasi (less-than) ordering relation on $\mathbf{F}$ such that $[\alpha] *[\beta]$ is read as " $[\alpha]$ is less than $[\beta]$," where $[\alpha] *[\beta]$, it satisfy conditions D4, D5 also.

9. $\operatorname{exc}_{n}$ is a mapping from $O$ into $(\mathbf{F} / \Leftrightarrow)^{n}$ satisfying conditions D28-D30, D35, D36. 
10. agst is a mapping from $\mathbf{F} / \Leftrightarrow$ into $O \times O$ satisfying conditions (7)-(12), (16), D1-D7, D15-D37.

The truth conditions of Boolean combinations of Judaic pragmatic-syllogistic formulas in a Judaic pragmatic-syllogistic model are understood in the way:

\section{Definition 10}

$\begin{array}{llll}\mathrm{M} \mid=\neg \varphi & \text { iff } & \mathrm{M} \mid \neq \varphi \\ \mathrm{M} \mid=\varphi \wedge \psi & \text { iff } & \mathrm{M} \mid=\varphi \text { and } \mathrm{M} \mid=\psi \\ \mathrm{M} \mid=\varphi \vee \psi & \text { iff } & \mathrm{M} \mid=\varphi \text { or } \mathrm{M} \mid=\psi \\ \mathrm{M} \mid=\varphi \Rightarrow \psi & \text { iff } & \mathrm{M} \mid=\neg \varphi \text { or } \mathrm{M} \mid=\psi\end{array}$

Thus, Judaic pragmatic-syllogistic allows us to take a final decision within disputes of the sages. It defines pragmatic limits for Talmudic debates.

Judaic argumentation theory considers pure formal-logical aspects of three groups of proofs from the pragmatic standpoint: proofs as trees, proofs as parallel processes, proofs as competitive communication. All groups can be regarded from the viewpoint of symbolic logic.

Open Access This article is distributed under the terms of the Creative Commons Attribution License which permits any use, distribution, and reproduction in any medium, provided the original author(s) and the source are credited.

\section{References}

Abraham, M., D. Gabbay, and U. Schild. 2009. Analysis of the talmudic argumentation a fortiori inference rule (kal-vachomer) using matrix abduction. Studia Logica 92(3): 281-364.

Abraham, M., D. Gabbay, and U. Schild. 2010. Obligations and prohibitions in talmudic deontic logic. In Deon 2010 proceedings, ed. Governatori, G. and Sartor, G. Springer, LNCS.

Aczel, P. 1988. Non-well-founded sets. CSLI Lecture Notes. California: Stanford.

Hirschfeld, H.S. 1840. Der Geist der talmudischen Auslegung der Bibel. Der erste Teil. Halachische Exegese. Ein Beitrag zur Geschichte der Exegese und zur Methodologie des Talmud's. Berlin: M. Simion in Berlin.

Hirschfeld, H.S. 1847. Der Geist der ersten Schriftauslegungen. Oder: Die Hagadische Exegese. Ein Beitrag zur Geschichte der Exegese und zur Methodologie des Midrasch. Berlin: M. Simion in Berlin.

Jacobs, L. 1984. The Talmudic argument: A study in Talmudic reasoning and methodology. Cambridge: Cambridge University Press.

Roth, J. 1986. The Halakhic process: A systemic analysis. NY: Jewish Theological Seminary of America.

Schumann, A. 2008. Non-well-foundedness in Judaic logic. Studies in Logic, Grammar and Rhetoric 13 (26): 41-60.

Schumann, A. (ed.) 2010. Judaic logic. Piscataway, NJ: Gorgias Press.

Schumann, A. 2011a. Qal Wa-Homer and the theory of massive-parallel proofs. History and Philosophy of Logic 32(1): 71-83.

Schumann, A. (ed.) 2011b. Modern review of Judaic logic. Special issue of History and Philosophy of Logic, 32(1).

Schumann, A. 2012. Talmudic logic. London: College Publications.

Schwarz, A. 1897. Die hermeneutische Analogie in der talmudischen Litteratur. Wien: Verlag der Israel.theol. Lehranstalt.

Schwarz, A. 1901. Hermeneutischer syllogismus in der talmudischen literatur. Karlsruhe, Bielefeld: Israelitisch-Theologischen Lehranstalt. 